\title{
Grundtvig om samfundspagt, gensidig frihed og menneskerettigheder i ca. 1840: Med en kommenteret tekstudgivelse.
}

\section{Af Kim Arne Pedersen}

Som baggrund for udgivelsen af to hidtil utrykte tekster af Grundtvig fra 1840 skitseres Grundtvigs skabelsesteologisk og kontraktteoretisk begrundede frihedssyn: at ethvert samfund er grundlagt på en kontrakt, en overenskomst, der finder sit udtryk i en udformet sammenfatning, en "Grundlov", der for Grundtvig skal være mundtlig, men hos ham selv også kan være skriftligt udformet. Denne grundlov bliver til gennem en pagtsslutning, i første række mellem Gud og menneske, skaber og skabning, deraf i afledet form i det borgerlige samfund mellem kongen og folket og i det kristne samfund mellem Gud og menneske i dåben. Samfundets grundlov udtrykker dét gensidige forhold mellem to parter, som samfundspagten indebærer, og på dette hviler Grundtvigs dialogiske frihedsbegreb. I de aftrykte tekster ses, hvorledes menneskerettighederne for Grundtvig afledes heraf, og hvorledes den nævnte grundlov for Grundtvig skal være offentlig og mundtlig.

Grundtvigs frihedsbegreb dukker med jævne mellemrum op i den offentlige debat og har $\mathrm{i}$ de senere år været drøftet $\mathrm{i}$ forhold til samfundets grundlag - spørgsmålet er, om et nationalt forstået folkefællesskab eller de universelle menneskerettigheder skal danne udgangspunkt for et givet samfund og dets regulering af borgernes liv med hinanden. Således har Jesper Langballe kontrasteret en "nationalistisk" Grundtvig og "tidens menneskerettighedsidealer" (Langballe 2002 , 111) i tråd med et ønske om at bringe Grundtvig på afstand af den europæiske oplysning og dermed moderniteten. I det følgende fremdrages to hidtil utrykte tekster af Grundtvig, hvori han knytter kontraktteori, frihedstænkning og menneskerettigheder sammen, tekster, hvis bærende synspunkter understøttes af forfatterskabets trykte tekster.

Det er Grundtvigs synspunkt, at ethvert samfund er grundlagt på en kontrakt, en overenskomst, der finder sit udtryk i en sammenfatning, en "Grundlov", der for Grundtvig skal være mundtlig, men hos ham selv også kan være skriftligt udformet. Denne grundlov bliver til gennem en pagtsslutning, i første række mellem Gud og menneske, skaber og skabning, deraf $\mathrm{i}$ afledet form $\mathrm{i}$ det menneskelige og borgerlige samfund mellem først kongen og folket, dernæst mennesker indbyrdes. Ydermere er der tale om et tredje led - ånden, der er bundet 
til et ydre samfundskonstituerende ord, det ord, der sikrer forbindelsen mellem de to parter i pagten. Grundtvigs frihedsbegreb er således tænkt og formuleret på baggrund af hans tanker om fællesskab og samfund, idet det af Grundtvig er tænkt i uløselig sammenhæng med det jeg-du-forhold, som forholdet mellem Gud og menneske udgør, det jeg-du-forhold, der som udgangspunkt har pagtsslutningen mellem Skaberen og skabningen. Ånden "knytter" mennesket i "Sjæl og Hjerte" til Gud, og der opstår dermed et "Samfund mellem Sjælen og Sandhed i Aanden" ( $D V$ II, 191). Det er træffende blevet sagt, at åndsbegrebet i Danne-Virke er præget af det "større, som ligger i "sam-et" menneske og menneske imellem" (Eichberg 1998, 148), og som i årene efter 1825 fører Grundtvig til at karakterisere forholdet mellem Gud og menneske som et forhold, hvor mennesket kan "tale med sin Gud, som en Mand med sin Næste" (Begtrup 1924, 147). Grundtvigs tanker om gensidigheden er baggrunden for Kaj Thanings præcise redegørelse for Grundtvigs frihedsbegreb. Grundtvigs "Liberalisme", eller, som Thaning med rette kalder det, hans "Frihedssyn" (Thaning 1949, 39), er engelsk og ikke kontinentalt. Det betyder for det første, at der er tale om en frihed, der i modsætning til principielle overvejelser har rod i den engelske pragmatisme - "it works well" - for det andet, at friheden for Grundtvig kun har en mening: "Respekten for Menneskelivet, for Mennesket" (ibid., 38), "Frihed eksisterer kun dér, hvor Livet mellem Mennesker anerkendes, æres, gavnes" (ibid., 38), siger Thaning med forudgribelse af tesen i disputatsen For menneskelivets skyld - Grundtvigs opgør med sig selv I-III fra 1963. Thaning refererer Grundtvig således, at "Kun den er fri, der vil lade Næsten være det med sig" (ibid., 38), det vil sige, at "Den enkelte er først fri, naar hans Næste er fri, er anerkendt" (ibid., 38). I selve udformningen af det grundtvigske frihedsbegreb skaber Thaning et Grundtvig-citat ud af en indirekte sammenhæng hos Grundtvig. Grundtvig gør det klart, at han i sin tilgang til spørgsmålet om frihed er mere realistisk end den tyske idealisme, der i Kants følgeskab taler om den moralske handlen som en ren handlen ud af frihed. Grundtvig fortolker Kants sammenkædning af frihed og autonomi som maskeret egennyttig individualisme:

thi vel tør jeg ikke, som en Tydsker, rose mine rene Hensigter, men De veed nok, man kan være meget ligegyldig ved Næstens Frihed, ja, endogsaa være en Hader derad, og dog føle meget varmt for sin egen Frihed, og da jeg nu selv er en gammel Bogmager af Haandværk, og er ligesaalidt i Kridthuset hos det ny Ministerium, som jeg var det hos det gamle Cancelli, saa vil De nok troe mig paa mit Ord, at jeg af Hjertet ønsker almindelig Trykke-Frihed, som den eneste mulige Maade, 
hvorpaa jeg selv kan være den mig ganske uundværlige Frihed nogenlunde vis (Grundtvig 1849a, 97).

Grundtvig gør det således klart, at netop denne gensidige frihed ikke blot tilgodeser det enkelte menneskes, men to eller flere menneskers frihed. Selv om Thaning danner et Grundtvig-citat ud af en indirekte sammenhæng, bliver der i nedenstående artikel argumenteret for, at han sagligt set har ret $\mathrm{i}$ at udlægge Grundtvig således. I den forbindelse tolkes dette grundtvigske frihedsbegreb således, at det som hørende sammen med det, Grundtvig betegner det naturlige menneskeliv, sætter ord på ethvert menneskes rimelige ret til selvudfoldelse, idet der, som det fremgår af ovenstående citat, kan argumenteres for den gensidige frihed på baggrund af egne forventninger og ønsker. Den afgørende formel, hvorunder Grundtvigs frihedssyn kan sammenfattes, er det dialogiske frihedsbegreb, som K. E. Bugge har påvist, har rødder $\mathrm{i}$ dansk samfundsdebat $\mathrm{i}$ tiden efter den franske revolution. Bugge arbejder med en oprindelig påvirkning fra den danske debat og en efterfølgende påvirkning fra den engelske liberalisme, hvor friheden i højere grad er en frihed til konkurrence og kamp. Om den danske tradition skriver Bugge:

Som ung kandidat havde han tilsluttet sig Rahbeks danske frihedsbegreb, ifølge hvilket friheden - i modsætning til den tøjlesløshed, som man havde været vidne til i revolutionstidens Frankrig bestemtes som en frihed, der er begrænset af moralens og fornuftens bud om ikke at øve vold mod næsten (Bugge 1965, 293).

Grundtvigs frihedsbegreb er begrundet i hans pagtstænkning, og fra 1820 'ernes slutning og frem løber hans teologiske overvejelser her sammen med den afhængighed af den kontraktteoretisk udformede samfundstænkning, som Tine Damsholt, blandt andet inspireret af Vagn Wåhlin, med baggrnnd i den norske historiker Jens Arup Seips begreb om "den opinionsstyrede enevælde", har påvist er baggrunden for Grundtvigs politiske tænkning (Damsholt 1995, 140 ff.). På denne baggrund giver det mening at tale om Grundtvigs dialogiske og kontraktteoretiske frihedsbegreb - et frihedsbegreb, der er uløseligt forbundet med hans tanker om ord og sprog som det konstitutive ved mennesket, ja det, der udgør menneskets gudbilledlighed. Grundtvigs forståelse af friheden kan med hans egne ord karakteriseres som "den gjensidige Frihed", der skal være "det borgerlige Selskabs Grundlov" $(M M, 79$ ff.), den gensidige frihed, der i første række angår forholdet mellem kongen og folket, men i videre forstand også er kernen i forholdet mellem mennesker i samfundet. For Seip er det afgørende at slå fast, at teorien om den opinionsstyrede enevældes "motstykke" er tanken om "kongedømmet av Guds nåde" (Seip 1958, 407) - Seip inddrager J. S. Sneedorffs forfatterskab, hvoraf det fremgår, at 
"fyrstens makt er grunnet på "folkets samtykke": "den naturligste Oprindelse til Stater er altsaa Pagt" (ibid., 408). Som det fremgår af nedenstående tekst, indebærer den grundtvigske udgave af denne samfundspagtsteori en afvisning af Kongeloven som det danske samfunds grundlov, parallelt med at Grundtvig som en grundlovs karakteristika fremhæver offentlighed, mundtlighed og - hvad der er meget vigtigt i nærværende sammenhæng - gensidighed. En grundlov angår altid forholdet mellem en konge og et folk, der har gensidige forpligtelser og rettigheder. Som nævnt er det Tine Damsholts fortjeneste at have påvist Grundtvigs afhængighed af den opinionsstyrede enevælde. Tydeligst kommer gensidighedsaspektet til udtryk i Grundtvigs redegørelser i højskoleskrifterne fra 1830'erne. Som påvist af Tine Damsholt er "Kongehaand og Folkestemme" lig med den besluttende og udøvende kongemagt og den folkeforsamling, der finder frem til "det fælles Bedste", det, som Grundtvig i Om Constitution og Statsforfatning $i$ Danmark angiver som lig med en folkelig styreform i modsætning til en styreform, hvor "Enhver raader sig selv”. I Grundtvigs samfundstænkning er både kongehånd og folkestemme i besiddelse af frihed, men de har forskellige opgaver:

Kæmpeskridtet er denne Gang Kongens, ligesom det 1660 var Folkets, og skal dets Følger blive det forriges værdige, da maa Folke-Friheden og den levende Virksomhed i alle gavnlige Retninger udvikle sig lige saa rolig og læmpelig, velgjørende og fuldstændig af den fri Folkestemme, som Folke-Ligheden, Rets-Pleien og hele den borgerlige Orden udviklede sig af det landsfaderlige Eneherredømme, uden at vi tabe det mindste af, hvad vi derved har vundet (HGS I, 28).

Grundtvig taler i tekstens fortsættelse om, hvorledes "en folkelig Dannelse i kongelig Aand" skal "gaae Haand i Haand med det folkelige Statsraad" (ibid., 28) og konkretiserer således forholdet mellem kongen og folket i en appel til virkeliggørelsen af folkehøjskoletanken. I nærværende arbejde skal forholdet mellem konge og folk imidlertid forfølges gennem en række af Grundtvigs kirkelige tekster fra 1830'erne, idet det påvises, hvorledes selve kontrakt-begrebet for Grundtvig står centralt og også bringes i anvendelse i forbindelse med hans tanker om kirken som et samfund, der konstitueres af den apostoliske trosbekendelse. Grundtvig udarbejder sit begreb om pagtsslutningen ved at lade begrebet om den opinionsstyrede enevælde vekselvirke med sine kirkelige tanker om trosbekendelsen.

Grundtvig er i sit forfatterskab fuldt bevidst om, at han paralleliserer statssamfundet og kirkesamfundet, og at begge samfund hviler på et fikseret grundlag, som parterne tilslutter sig mundtligt og $\mathrm{i}$ offentlighed og kontraktligt forpligter sig til at overholde. Den grund- 
læggende lighed mellem de to former for samfund giver sig altså af, at begge typer må være i besiddelse af en uforanderlig kerne, noget, der står fast uanset forandringerne. Grundtvig slår fast, at "Den christne Kirke, vi tale og trættes om, er jo i Grunden slet ikke Andet end et Menneske-Samfund eller en Menighed, med en nøie bestemt, vidunderlig Tro, ..." "et troende Menneske-Samfund med Saligheden for Øie" (US VIII, 287), idet "Eenheden" mellem de kristne for Grundtvig ligger i det "udvortes", lydelige "Guds og Troens Ord" (US VIII, 447). Kirken "opretter en Daabs-Pagt med sine Medlemmer om Syndernes Forladelse og det evige Liv", en dåbspagt, der indeholder de "Saligheds-Vilkaar" (US VIII, 166), hvis overholdelse er nødvendige. Grundtvig gør det klart, hvad kirkens status som samfund betyder, idet han inddrager de verdslige samfund i tiden efter den parisiske julirevolution:

I det nittende Aarhundrede er Man omtrent blevet enig om, at i StatsForfatninger betrygges Grund-Fastheden bedst ved et Adels-Kammer, som det engelske Over-Hus, men uden at ville foregribe Erfaringens Dom herover, som snart vil falde, tør Man dog nok paastaae, at enhver ubestemt Indskrænkning af Foranderligheden, der bliver stor, liden eller ingen, efter nogle enkelte Personers Klogskab, Mod og Kraft til at bestemme og overholde den, er i en oprørt Tid kun et nyt GiæringsStof, saa skal Noget hjelpe, enten i det ene Samfund eller i det Andet, maa det være en klar Udvikling af hvad Samfundet staaer og falder med, og som derfor under alle Omskiftelser maa være uforanderligt. Kommer det ei dertil, eller findes der ikke da i Samfundet Villie og Kraft til at bevare denne Kierne, der er som Hjertet i Planten, og som Bevidstheden i Mennesket, da er et uopreiseligt Fald uundgaaeligt, da forgaaer Samfundet, som Planten gaaer ud og Mennesket gaaer fra Samlingen; udvortes physisk Magt afløser da al indvortes aandelig Forbindelse, og Tilstanden bliver en uophørlig Vædde-Strid mellem Tøileløshed og voldsom Undertrykkelse (Anarchie og Tyrannie) om hvilken der bedst kan fortære, og først tilintetgiøre det opløste Samfunds Bestand-Dele, en Vædde-Strid, som den Ormene i Graven føre med Forraadnelsen (US V, 280-281).

Det ses, at Grundtvig bruger det antikke og paulinske organismebillede som udgangspunkt for sin indkredsning af, at ethvert samfund er bundet til et uforanderligt grundlag, en "Kierne", der svarer til "Bevidstheden i Mennesket". Grundtvigs bevidsthedsbegreb er ikke snævert bundet til menneskets refleksive evne, men forudsætter de evner, som udgør mennesket som helhed. Grundtvig fremhæver i skriftet om reformationen "den christne Troes Uforanderlighed" (US $\mathrm{V}, 325)$ som netop det grundlag, der konstituterer samfundet, dvs. "det mundtlige Vidnesbyrd om Troen" (US V, 326) som 
er Kirkens uforanderlige Troes-Regel og Grund-Lov, som i uopløselig Forening med Daaben sætter det eneste forsvarlige Skiel mellem Kirken og Verden, eller mellem den virkelige Christenhed og hvad der er det ikke (US V, 328).

Som det fremgår, er "den Christne Kirke (...) et Troes-Samfund, hvori Ingen maa optages ved Daaben, uden at aflægge den TroesBekiendelse, hvorved det Kirke-Samfund kiendelig adskiller sig fra ethvert Andet" (US V, 283), "vort Kirke-Samfund staaer og falder med vor Troes-Bekiendelse" (US V, 284), den afstikker de "Grcendser" (US V, 349), som gælder for trosfriheden. Kirkesamfundet "maa være kiendeligt for Støv-Øret paa det tydelige, offenlige, mundtlige Ord, hvormed Samfundets Medlemmer bekiende deres Tro og Haab" (US V, 378). "Sandheds-Tro til Salighed maa altid være eens, men kan ei være det, med mindre den udtrykkes eens i en uforanderlig TroesBekiendelse af alle Troes-Samfundets Medlemmer" (US VIII, 392). Det er afgørende, at "den mundtlige Troes-Bekiendelse ved Daaben og ingen muelig Skrift er eller kan være Kirkens Grundvold" (US VIII, 398). Forholdet mellem Gud og mennesket kommer således i stand ved dåben, idet den apostoliske trosbekendelse af Grundtvig opfattes som det kristne samfunds grundlov, den grundlov, mennesket kontraktligt forpligter sig på gennem forsagelsen af djævelen og sit frie ja til Guds tilbudte nåde, der finder sit udtryk i grundloven eller grundvolden. Denne grundvold karakteriseres af Grundtvig også som "den Troskabs-Eed, han lader sine Undersaatter aflægge ved Daaben, tilligemed Bekiendelsen af hvad de kan stole paa og vente sig i hans Rige" (US VIII, 382). Trosbekendelsen er som "Daabs-Pagt" (US V, 340) "Vilkaar for Optagelsen i Samfundet" (US V, 343), og det fremgår af Grundtvigs diskussion med vennen B. S. Ingemann om kødets opstandelse, hvor alvorligt han mener denne tale om det kristne samfunds "Grundlov" (Grundtvig 1882, 327). ${ }^{2}$ Grundtvigs parallelisering af kirke og samfund med grundloven som fælles motiv fører ham dels til at knytte overvejelser over grundloven sammen med en kritik af den danske kongelov, dels til at begrunde menneskerettighederne ved hjælp af det kontraktlige forhold, som regulerer forholdet mellem konge og folk.

Kritikken af kongeloven fremkommer således i skriftet om den lutherske reformations fortsættelse, hvor paralleliseringen mellem det verdslige og det kristne kongedømme bliver ført helt igennem. Grundtvig imødegår her den dengang almindelige opfattelse af kongeloven som det danske samfunds kontraktteoretiske begrundelse. ${ }^{3}$ For Grundtvig mangler kongeloven en grundlovs afgørende egenskaber: 
Sæt nemlig, der i et Land blev Spørgsmaal om Grund-Forholdet mellem Kongen og Riget, da kunde det vist nok ikke afgiøres efter FolkeSnak, men var der en Eed, som alle Kongerne, ved deres ThronBestigelse, aabenlydt og offenlig maatte aflægge, hvem kunde da tvivle om, at denne Eed, aflagt eens, saavidt Man vidste, fra ArildsTid, var det gyldigste historiske Vidnesbyrd om Grundforfatningen, der kunde gives? Vilde nu end Nogen paastaae, at en ældgammel, troværdig og vidtberømt Rigs-Krønike, uden Hensyn paa KroningsEden, skulde afgiøre Spørgsmaalet, og det uagtet den giennem flere Aarhundreder havde henligget næsten forglemt i Rigs-Archivet, da mener jeg, Man vilde neppe finde det Umagen værdt at vise det Ugrundede og Bagvendte i slig en Paastand. Indlod Man sig imidlertid derpaa, vilde det aabenbar være Nok at erindre, deels, at med al Agtelse for Archivarernes Ærlighed, og Afskrivernes Nøiagtighed, kunde Man umuelig ansee et skriftligt Vidnesbyrd, der strængt taget, kun var Disses, for saa sikkert, som det mundtlige, høitidelige, offenlige, tit gjentagne, der ikke blot var Kongernes, men, saa at sige, hele Folkets, fra Slægt til Slægt, og at, i alt var det Forhold Eden udtrykde det Virkelige, der havde fundet Sted, hvad enten det saa stemmede med Forskriften eller ikke, saa det var Eden, og ikke Skriften, der havde Forbindtlighed for Kongen! (US V, 330).

Tekstens udgangspunkt i "Grund-Forholdet mellem Kongen og Folket" er et godt eksempel på, hvor afgørende teorien om den opinionsstyrede enevælde er for Grundtvigs samfunds- og kirkesyn. Det ses, at Grundtvig prioriterer en mundtlig ed i forhold til et skriftligt dokument, idet parallellen mellem det verdslige og åndelige rige gennemføres med den danske kongelov som udgangspunkt. Ikke kongeloven, men den mundtlige ed ved tronbestigelsen er det konstitutive i det danske rige, kongeloven, der i modsætning til den mundtlige ed ikke har været offentlig. Kongeloven svarer til den kristne kirkes Bibel, der i rationalismens tid ikke har været agtet. Ud over offentlighedsaspektet har kongens ed det fortrin, at den "ikke blot var Kongernes, men, saa at sige, hele Folkets, fra Slægt til Slægt" på lignende måde, som kirkens trosbekendelse har været kirkens grundvold fra kirkens begyndelse, kirkens grundvold, som alle i kirken, høj og lav, har sagt ja til ved dåben. Grundtvig slår fast, at "i vort Kirke-Samfund er denne Bekiendelse da unægtelig Troes-Reglen og Grund-Loven" (US V, 331), der gør den "Christne Kirke kiendelig for Venner og Fiender" (US V, 332) og at "Skriften ikke skaber", men "beskriver" denne grundlov ( $U S \mathrm{~V}, 333)$. Grundtvigs synspunkter $\mathrm{i}$ grundlovsdebatten i 1849 støtter denne fortolkning. I forbindelse med Scavenius's forslag om at sikre kongens politiske indflydelse gør Grundtvig det klart, at kongens stilling fremover vil "beroe paa hans Personlighed" (Grundtvig 1849b, 1797). ${ }^{4}$ Grundtvig giver i den sammenhæng udtryk for, hvorledes han betragter Kongeloven, der for 
ham først og fremmest er ubrugelig som grundlov, fordi den i en årræke har været holdt hemmelig og altså været uden den offentlighedsdimension, den kristne trosbekendelse eksempelvis har:

Hvad nu Kongeloven angaaer, da har jeg selv erklæret, at jeg anseer dens høitidelige Ophævelse for nødvendig; men naar man vil paastaae, at det er en Grundlov, som vi egentlig, for at gaae historisk frem, maatte bygge paa, og som man kunde beraabe sig paa imod os, imod Rigsforsamlingen, der selv er sammenkaldt af den retmæssige Konge, da mener jeg, at dette er aldeles feil, thi Kongeloven, den fattes aabenbar som Grundlov hvad der maa være den første Egenskab ved en saadan, det er, at den ikke er eensidig, men gjensidig. Den er, som vi jo maae vide, aldrig forelagt nogen Rigsforsamling eller antagen af en saadan; den er, som vi ogsaa skulde vide, ikke udstedt af den Konge, som kunde tænkes at have havt Fuldmagt til at gjøre den til en Grundlov for Riget (skjøndt jeg ikke forstaaer det); den er ikke engang udstedt af ham, og det synes da Intet i mine Øine, om hans Navn end hundrede Gange findes underskrevet i Archivet; thi netop det, at den kun findes i Archivet, og efter Historien endog har været vanskelig at finde der, det beviser paa bedste Maade, at, hvad ogsaa Kongeloven var, havde Kongen ikke besluttet at udgive den som Grundlov. Hvad der hidtil har været Danmarks Grundlov, det er aabenbart den Overdragelse af Rigsdagen i Aaret 1660 til Frederik den Tredje af Enevoldsmagten og Arveligheden paa Mands- og Qvindelinien. Denne Overdragelse, modtagen af Kongen, har en Grundlovs første Egenskab og fattes kun den Egenskab, som en god Grundlov skal have: at fastsætte den Maade, hvorpaa Kongen i Grunden skal bruge sin Enevoldsmagt, saa at det kunde efter menneskelig Tanke blive til Gavn og ikke til Skade, blive til Godt og ikke til Ondt; thi her kan jo ikke være Spørgsmaal om, at naar det danske Folk igjennem Rigsdagen overdrog Kongen Enevoldsmagten, da var det ikke for at blive tyranniseret, da var det, fordi det troede, at den vilde i hans Hænder blive bedst og ligeligst anvendt til Folkets Gavn og begrunde den Frihed og Ligelighed, som det danske Folk aldrig har ophørt at elske og ønske (ibid., 1797).

For Grundtvig er det her ikke kongens mundtlige ed, der udgør grundloven, men derimod folkets overdragelse af magten - det vil sige stadig en mundtlig akt, men nu en akt, der forudsætter et kollektiv, en gruppe af mennesker. Samtidig rummer selve argumentationen imod kongeloven forbindelser tilbage til 1830'erne. I nærværende sammenhæng skal tre elementer i Grundtvigs tale fra 1849 fremhæves: først, at en sand grundlov for Grundtvig må være "gjensidig", det vil sige, at den har karakter af en pagtsslutning, hvor begge parter - i forlængelse af Grundtvigs dialogiske grundsyn - både tilkendes rettigheder og forpligtelser, dernæst, at grundloven skal være offentlig. 
Endelig er det væsentligt, at grundloven rent indholdsmæssigt sætter nogle grænser for kongens magt - et tema, der kunne udfoldes mere, og som står i forbindelse med ministeransvarligheden som grundtvigsk ledemotiv. ${ }^{5}$ Vigtigt er, at Grundtvig i den videre debat giver udtryk for sine ønsker om, at den kommende danske grundlov vil give rum for kongen - kongens rettigheder - i lighed med, at "Folket" ikke i 1660, som det dengang blev hævdet, ved magtoverdragelsen til kongen havde "tilintetgjort sig selv" (ibid., 1800). Grundtvigs tanker om kongens og folkets gensidige rettigheder danner som omtalt baggrund for hans positive forhold til menneskerettighederne.

Der blev til indledning gjort rede for, at Jesper Langballe mener, Grundtvig er modstander af de universelle menneskerettigheder. I den sammenhæng er der grund til at pege på historikeren Lars Kaaes påvisning af rettighedstænkningens nedslag i Grundtvigs forfatterskab. Kaae bevæger sig i sin afhandling om Grundtvigs frihedssyn indirekte ind på Grundtvigs forhold til menneskerettighederne, idet han påviser, at "retten til arbejde" (Kaae 1983, 114) som en friheds- og altså dybest set en menneskerettighed ligger bag hele Grundtvigs sociale tænkning, "samfundet skal give den enkelte mulighed for at tjene sit daglige brød" (ibid., 115). Som støtte for Kaaes analyser kan nævnes, at Grundtvig selv træffende har talt om "Folkets Selv-Besiddelse" som en "utabelig Rettighed" (Grundtvig 1848, 218 f.) og således knyttet til ved den moderne rettighedstænkning. Kaaes fortolkning modsiges kun tilsyneladende af Grundtvigs kritik af menneskerettighederne i Mands Minde, for denne kritik er ikke absolut. Grundtvigs anklage mod revolutionens menneskerettighedsbegejstring retter sig først og fremmest mod det forhold, at der i det revolutionære Frankrig ikke var en stærk stat, der kunne sikre menneskerettighederne $(M M, 91,100$ ff.), og få år før Mands Minde-forelæsningerne kan Grundtvig i skriftet om den lutherske reformations fortsættelse slå fast, at "SamvittighedsFriheden" er "en umistelig Menneske-Ret!" (US V, 308). Grundtvig gør det i Mands Minde klart, at holder man sig til menneskenaturen, vil fyrste og folk arbejde sammen, man vil indse, "at Kongens og Folkets Frihed, ret forstaaede, langt fra at være uforenelige, meget mere kræve hinanden" $(M M, 127)$, og Grundtvig kan - i direkte forlængelse af det "thaningske" princip, at kun den er fri, der lader næsten være fri med sig - konkludere, at "gjensidig Frihed og den gode Orden, som deraf udspringer" er "det borgerlige Selskabs Grundlov" (ibid., 128). Grundtvigs tanker om "gjensidig Frihed" sigter mod forholdet mellem en kongelig dømmende, lovgivende og udøvende myndighed og en "sand Borger-Frihed" (ibid., 79), det vil sige i første række den "fri folkestemme", friheden til, at en borgerlig offentlighed kan ytre sig, samt de frihedsrettigheder, der flyder deraf. Det er således som vist 
ovenfor en grundtanke i forfatterskabet, at ligesom folket "frigjorde" kongen i 1660, er det nu kongens opgave at "frigøre" folket - og dette kan fortolkes i tråd med John Lockes grundlæggelse af menneskerettighederne. ${ }^{6} \mathrm{I}$ årene efter Mands Minde tænker Grundtvig videre over menneskerettighederne. I sin nyudkomne bog om Grundtvig og kampen mod slavehandelen fremdrager K. E. Bugge Grundtvigs tale i Danske Samfund, oktober 1841, hvori Grundtvig knytter en polemik mod, at mennesker holdes som slaver, sammen med en fremhævelse af, at mennesket er skabt i Guds billede med taleevne - et forhold, der begrunder, at mennesket er "bedre værd end selv at gaae i Slaveriet og flaaes ved Leilighed" (Fasc. 364. III. 62, op. cit. Bugge 2003, 96). Når det forholder sig sådan, er mennesket skabt til at herske over jorden og kan ikke være slave af andre - trællestanden tilkommer de umælende. Bugges fremdragelse af talen om menneskerettigheder fra Danske Samfund kan formodentlig suppleres med en tekst fra næsten samme tid. Det drejer sig om Fasc. 189.I, hvori Grundtvig i 1840 i anledning af Christian VIII's tronbestigelse skriver en Politisk Troes-Bekiendelse og Tanke-Gang. Grundtvig ønsker med sit aldrig udgivne udkast "at befæste den vaklende Tro, hvorpaa det borgerlige Selskab hviler" og han gør det - efter at have streget et forsvar for "Enevoldsmagt" klart, at han er "en Ven saavel af Borgernes Frihed og Rettigheder, som af Kongens". Titlen Troes-Bekiendelse skal tages ganske konkret. I lighed med, at en "Pagt" indstifter det kristelige forhold mellem Gud og menneske, indstifter en pagt forholdet mellem mennesker, i første række forholdet mellem folket og monarken, og så, med det som grundmodel, forholdet menneske og menneske imellem, hvor kun den er fri, der lader sin næste være det med sig. Og ligesom den kristelige dåbspagt er grundet på en trosbekendelse, er det tilfældet $\mathrm{i}$ borgerlivet. Som det er fremgået af ovenstående, er friheden for Grundtvig grundet i en pagt, en overenskomst eller aftale, der som en grundlov er sprogligt fikseret, om end den sproglige form gerne kan være mundtligt overleveret. I sit forsøg på at udforme denne grundlov, skriver Grundtvig i sin første "Troes-Artikel", svarende til troen på Skaberen, "at $i$ et vel indrettet borgerlig Selskab maa kun Én have Ret til at byde og alle Undersaatterne være pligtige til at lyde", den anden trosartikel er da, at ligesom kongen har "fri Haand" skal "Undersaatterne" have "fri Mund" - med tematiseringen af Kongens hånd bevæger Grundtvig sig ind i den kongelige handlen, svarende til frelsergerningen i Kristus. Grundtvig når nu i tredje trosartikel frem til menneskerettighederne og skriver:

Min tredje Troes-Artikel er den, at Mennesket er ikke til for Statens eller det borgerlige Selskabs Skyld, men Staten med alle sine Indret- 
ninger er til for Menneskets Skyld, saa / [alle] / virkelige MenneskeRettigheder maa ingen Øvrighed krænke, skal alle Undersaatter nyde (Fasc. 189.I).

Rettighedstænkningen svarer til trosbekendelsens redegørelse for Helligåndens gerning og dermed for menigheden! Teksten afdækker, hvorledes Grundtvigs tanker om "gjensidig Frihed" i første række har kongens og folkets gensidighed som mål - men samtidig er det klart ud fra Grundtvigs skrifter i 1830erne, at tanken om den gensidige frihed ikke blot har denne overordnede sammenhæng som konkretion, men også gælder i samfundet som helhed. ${ }^{7}$ I den næstfølgende tekst fremlægger Grundtvig en detaljeret kritik af Kongeloven, og samtidig gør han det klart, at det kontraktlige, gensidige forhold mellem folk og konge også medfører forpligtelser for kongen. I tekstens slutning bevæger Grundtvig sig ind på en Locke-inspireret redegørelse for, hvad der udgør kernen i menneskerettighederne. Den teologisk og kontraktteoretisk begrundede tanke om gensidig frihed er udgangspunkt for Grundtvigs tilslutning til de universelle menneskerettigheder, en tilslutning, der for ham ikke står i modsætning til tanken om national identitet. Dette bør offentligheden være opmærksom på i disse år, hvor Grundtvig benyttes i den politiske og kulturelle kamp i Danmark.

\section{Udgivelsen}

Det første manuskript, Fasc. 189.I, betitlet Politisk Troes-Bekiendelse og Tanke-Gang er skrevet på maskinpapir og består af et læg med to blade i kvartformat. Det er ifølge Registranten afmærket med den bølgestreg, der på dette tidspunkt har afløst Grundtvigs oprindelige I.J.N. over manuskripterne. Det næstfølgende manuskript Fasc. 189.II er ligeledes skrevet på maskinpapir, er i kvartformat og indeholder 1 læg i 2 blade uden nogen form for mærkning. Teksten er tilstræbt gengivet ordret og med Grundtvigs tegnsætning. En række sproglige smårettelser er ikke aftrykt eller markeret, hvorimod større overstregninger er gengivet i noterne.

\section{Litteraturliste.}

Begtrup, H. (1924), N. F. S. Grundtvigs Vartovs-Prcedikener 18391860, København.

Brun, H. (1882), Biskop N. F. S. Grundtvigs Levnetsløb, udførligst fortalt fra 1839. Et Bidrag, 1-2, bind 2, Kristiania.

Bugge, K. E. (1965), Skolen for livet, Studier over N. F. S. Grundtvigs padagogiske tanker, København. 
Bugge, K. E. (2003), Grundtvig og slavesagen, Århus.

Damsholt, T. (1995), “'Jeg er en gammel Royalist, det ved De nok'. Elementer i Grundtvigs politiske tænkning", Grundtvig-Studier 1995, København, 140-162.

$D V$ II = Grundtvig, N. F. S. (1817), "Om Mennesket i Verden", Danne-Virke, et Tidsskrift, bind 2, København.

Eichberg, H. (1998), "Modernitetens modsigelser: Konfigurationskonflikter og samfundstænkning i Grundtvigs 'Om Mennesket i Verden"”, Grundtvig- Studier 1998, København, 142-156.

Griffenfeld, Peder Schumacher (2003), Kongeloven af 1665, lokaliseret på World Wide Web 2. august 2004:

$\mathrm{http} / /$ www.danskekonger.dk/biografi/andre/kongeloven.html

Grundtvig, N. F. S., Politisk Troes-Bekiendelse og Tankegang, Fasc. 189.I.

Grundtvig, N. F. S., Fasc. 189.II.

Grundtvig, N. F. S. (1848), "Den danske, den tydske og den franske Sag”, Danskeren. Et Ugeblad, 1. Aargang nr. 2, 4, 8, 10, 11, 14, 15, København.

Grundtvig, N. F. S. (1849a), "Tale for Trykkefriheden", Danskeren. Et Ugeblad, 2. Aarg. 24. Feb. 1849 Nr. 7, København.

Grundtvig, N. F. S. (1849b), Rigsdagstidende 1849, No. 229, 17971800.

Grundtvig, Svend (1882), Grundtvig og Ingemann. Brevvexling 18211859. Udgiven og indledet af Svend Grundtvig, København.

HGS I = Grundtvig, N. F. S. (1929), "Det danske Fiir-Kløver" (1836)

i Ernst J. Borup og Frederik Schrøder, Haandbog $i$. F. S. Grundtvigs Skrifter, bind 1, København, 16-45.

$H G S$ II = Grundtvig, N. F. S. (1929), "Om Constitution og Statsforfatning i Danmark" (1848), i Ernst J. Borup og Frederik Schrøder, Haandbog $i$ N. F. S. Grundtvigs Skrifter, bind 2, København, 189-191.

Kaae, L. (1986), "Ikkun som voxne Menneskebørn. Grundtvig og frihed" i V. Tønnes Bekker-Nielsen et al., Stykkevis og delt. 5 essays om Grundtvig og grundtvigianisme, Århus, 57-122.

Langballe, J. (2002), “Den danske sag”, Tidehverv, Nr. 5, årg. 76, 111 28.

Leisner, J. (1972), "Zeitgeist, Nogle idéhistoriske betragtninger" i J. Leisner et al. (red.), Festskrift til Poul Bagge på halvfjerdsårsdagen 30. november 1972, København, 203-213.

Lund E., Pihl M. og Sløk J. (1963), De europaiske ideers historie, København. 
$M M=$ Grundtvig, N. F. S. (1877), Mands Minde, 1788-1838 Foredrag over det sidste halve Aarhundredes Historie holdte 1838, København.

Overgaard, U. (2003), En analyse af Martin Bubers antropologi, teologi og padagogik, gennemiført under inddragelse af den danske folkehøjskoles identitetskrise og N.F. S. Grundtvigs tanker om gudsforholdet, den mellemmenneskelige relation og samtalen, Kandidatspeciale i teologi, Aarhus Universitet.

Seip, J. A. (1958), "Teorien om den opinionsstyrte enevælde", Norsk historisk Tidsskrift, 38.

Thaning, K. (1949), "Grundtvig og den grundlovgivende Rigsforsamling”, Grundtvig Studier 1949, 2, København, 35-73.

Thaning, K. (1963), For menneskelivets skyld - Grundtvigs opgør med sig selv, I-III, København.

US V = Grundtvig, N. F. S. (1907), "Skal den lutherske Reformation virkelig fortsættes?" (1831) i Holger Begtrup, Nik. Fred. Sev. Grundtvigs Udvalgte Skrifter, bind 5, København, 278-355.

Ibid., "Nordens Mythologi eller Sindbilledsprog historisk-poetisk udviklet og oplyst (1832), 378-767.

US VIII = Grundtvig, N. F. S. (1907), "Kirkelige Oplysninger især for Lutherske Christne" (1840-41) i Holger Begtrup, Nik. Fred. Sev. Grundtvigs Udvalgte Skrtfter, bind 8, København, 370-457.

Ibid., "Den Christne Kirke og den Tydske Theologi", 161-169.

Noter

1 Artiklen henviser her til de ligheder mellem Grundtvigs tanker om forholdet mellem Gud og menneske og Martin Bubers dialogfilosofi, således som det er afdækket i ph.d.-stipendiat, cand. theol. Ulrik Overgaards utrykte specialeafhandling om Grundtvig og Buber. Afhandlingen arbejder i krydsfeltet mellem teologi og pædagogik og bevæger sig derfor udførligt ind på de to tænkeres antropologi. Forsøgsvis kunne man sammenligne Grundtvigs åndsbegreb og den "Ontologie des Zwischen" (Overgaard 2003, 60), som Buber arbejder med.

2 Nærværende artikels forfatter tilslutter sig således Niels Henrik Gregersens kritik af Christian Thodbergs tolkning af Grundtvigs dåbsteologi, som den er fremsat i dette års Grundtvig-Studier. Imidlertid kan det $\mathrm{i}$ den sammenhæng være gavnligt at kaste et blik på en ældre fortolkningsposition, hvori der i forbindelse med menneskets tilslutning til pagten sondres mellem løfte og aftale. Grundtvigs personlige bekendt og biograf Hans Brun skriver: "Endnu hører vi ikke sjelden Udtrykket Daabs-Løftet, skjøndt Herren gjennem Menigheden slet ikke spørger efter noget Løfte, men kun om han forsager og tror. Indgang og Udgang er fri hos Vorherre, saa hvem der vilde gaa ud fra Pagten igjen, maa ikke 
kaldes Løftebryder, men han gaar jo derved bort fra Løfterne, Vorherre har givet ham. Det er underlig, hvor længe det Tilvante kan sidde i en, ogsaa efter at Lyset er oprundet over en Egn af Aandens Verden, og da hvormange Præster der er, som dog vist har lyttet til Pagten, men endnu taler om "at gjentage sit Daabs-Løfte". Sidste Gang jeg hos Grundtvig selv i hans "Lejligheds-Taler" fandt Udtrykket "Løfte" om Pagten, det var i 1839. Med Tanken paa Rigs-Forholdet har han vistnok langt senere kaldt Daabs-Pagten “Troskabs-Eden”, men i Fest-salmerne synges dermod (1862), at ... Daabens Pagt Den er "intet Løfte”. Derimod betragter han den som en "ren Aftale", hvorefter den Troende med Jaet til Afsigelsens og Troens Ord har Ret til alt hvad Ordet byder paa" (Brun 1882, 701). Brun føjer en fodnote til: "At 'forsage' forklarede Grundtvig dels ved "ville blive kvit", dels ved "vende Ryggen til" (ibid., 701). Bruns fremstilling er bemærkelsesværdig, idet den med udgangspunkt i den sene Grundtvigs afklarede teologi fremhæver det kontraktlige i Grundtvigs dåbssyn og samtidig understreger, at dette ikke indebærer en præstation fra menneskets side, ikke indebærer menneskets medvirken i frelsesværket.

Lund, Pihl, Sløk (1963) har med rette peget på Kongelovens kontraktteoretiske baggrund: "Det er tidligere omtalt, hvilken rolle romerretten spillede som rustkammer for den teoretiske begrundelse af den absolutte fyrstemagt af Guds nåde. Under den store politiske fremgang for enevælden i det 15., 16. og 17. århundrede kombinerede man som regel argumenter herfra med den støtte, man kunne finde i Bibelen. Dette gjorde man også i nogen grad i den eneste skrevne enevoldsforfatning, Europas historie overhovedet kender, nemlig den danske kongelov fra 1665. Selve navnet Lex Regia er hentet lige ud af romerretten, og i begrundelsen af enevælden er det mest teokratiske synspunkter, man bruger (...) Men den danske kongelov viser sig ved nøjere eftersyn i langt højere grad at være båret af ganske andre og for den tid helt moderne anskuelser, hentede fra naturretten" (Lund, Pihl, Sløk 1963, 247-248). "Nogle mente, at man nok havde betroet ledelsen af staten til en fyrste, men således, at overdragelsen var sket på visse vilkår, som fyrsten måtte overholde; suveræniteten beholdt folket, idet den er udelelig og umistelig, og overholdt fyrsten ikke vilkårene, fortabte han sin egen ret til at regere og kunne da afsættes. Grotius ville ikke gå helt så vidt: fyrsten havde en moralsk pligt til at overholde menneskerettighederne, men folket kunne ikke tvinge ham, medmindre det udtrykkeligt stod i forfatningen" (ibid., 248) Hvor Hobbes hævder "fyrstens uindskrænkede suverænitet" er der ifølge Lund, Pihl, Sløk for Grotius visse begrænsninger, og "I den danske kongelov fulgte man (...) mere Grotius' end Hobbes' anskuelser" (ibid., 249). Samtidig bør det ikke overses, at der virkelig er tale om kongens absolutte arvemagt. Det er Peder Schumachers - altså Griffenfelds fortjeneste, at den danske Kongelov knytter til ved tanken om samfundspagten, men Kongeloven gør det i den sammenhæng klart, med Frederik III's ord fra 1665, at i forbindelse med Københavns belejring 
blev "Voris da værende Rigens Raad og samptlige Stænder, Adel og Uadel, Geistlig og Verdslig dertill bevæget deris forrige Kaar og Wallrettighed at affstaa og begiffve, den tillforne aff Os underskreffne Haandfestning med alle sine Gienparter, Puncter og clausuler død, magtesløs og till intet at giøre", således at kongen nu har fået "Jura Majestatis, absolute Magt, souverainitet og alle Kongelige Herligheder og Regalier utvungen og uden nogen voris Tillskyndelse" (Griffenfeld 2003).

4 Jeg takker universitetslektor, ph.d. Regner Birkelund for henvisningen.

5 Grundtvig fortsætter sin redegørelse med at slå fast, at spørgsmålet om kongens indflydelse først og fremmest skal være ledet af spørgsmålet om folkets "Frihed og Rettigheder" (Grundtvig 1849b, 1797), idet kongens magt er uløselig forbundet med spørgsmålet om ministeriets magt og først og fremmest - ansvar, "den Borgen og Sikkerhed, som Ministrene maae give og alene kunne give Folket for dets Frihed og Rettigheder" (ibid. 1797). I debatten bevæger Grundtvig sig også ind på "Magtens Deling" (ibid.1800).

6 I den sammenhæng bør Lockes udgave af samfundspagten tænkes med, for Locke var alle mennesker "i naturtilstanden født lige, frie og uafhoengige, og de var i besiddelse af ejendom, dvs. de ejede deres liv, deres frihed og deres gods", besad altså nogle naturlige rettigheder. Dette er for Locke forbundet med pagtstænkning, "Pagtens indhold blev naturligvis begrænset til, hvad det almene vel krævede. Dette hensyn var derfor det eneste, der kunne motivere indskrænkninger $\mathrm{i}$ de nævnte naturlige menneskerettigheder. Da man imidlertid ikke gav afkald på mere af friheden, end det var nødvendigt for varetagelsen af alles naturlige rettigheder, fulgte heraf, siger Locke, at selve suverceniteten blev hos folket, og at menneskerettighederne som sådan også fortsat bevarede deres fulde gyldighed" (Lund, Pihl, Sløk 1963, 251).

7 Selv om der i Om Constitution og Statsforfatning $i$ Danmark er en kritik af rettighedstænkning som abstrakt teoretiseren uden hensyntagen til livet som det er, kan Grundtvig alligevel der tale om, at "en god Grundlov" "tildeler baade Kongen og Folket alle de Friheder og Rettigheder, som er til foelles Bedste" (HGS II, 191). Grundtvig eksemplificerer dette ved at gøre rede for kongens forpligtelser over for folket: “...forpligter Kongen sig højtidelig til at holde denne Grundlov, er Hans Raad hele Folket ansvarligt for at det skeer, og har Folke-Stemmen baade mundtlig og skriftlig frit Raaderum, da er vor saakaldte Stats-Forfatning ægte Dansk," (ibid., 191). 
Fascikel 189.I. (Læg 1) (1r)

\title{
Politisk Troes-Bekiendelse og Tanke-Gang
}

\author{
Af Nik. Fred. Sev. Grundtvig.
}

\section{Forord.}

Der er en Tid til at tie og Tid til at tale, siger den kongelige Viismand, og jeg skiønner ikke rettere, end at enhver Dannemands politiske Troes-Bekiendelse nu vil være Ord i rette $\mathrm{Tid}^{1}$; thi paa den ene Side udraaber Man lydelig mange Sætninger for hele Folkets Overbeviisning, som er langt fra at være det, og paa den anden Side er Folkets borgerlige Tro ligesaa svag og beleiret af Tvivl, som dets kirkelige, saa de fleste vakle og hælde til den Mening, de hørde sidst forklaret. Under saadanne Omstændigheder er det vist nok ikke stort, en Mand, der ikke følger Strømmen, kan udrette med Pennen, som ikke kan svare de flydende Tunger Eet til Tusinde, men i saadanne Tider maa ikke det Mindste, der kan tjene til at befæste den vaklende Tro, hvorpaa det borgerlige Selskab ${ }^{2}$ hviler, foragtes eller forsømmes, og under vor ny Konge, som fra Ungdommen af er fortrolig med alt hvad der giærer og kæmper i Tiden, kan og bør en Ven ${ }^{3}$ saavel af Borgernes Frihed og Rettigheder ${ }^{4}$, som af Kongens, tale langt friere og tydeligere end under vor gamle // (2v) Landsfader, som, med det kongeligste Hjerte og den bedste Villie, dog umuelig kunde gaae ind paa de nye Synspunkter, hvorfra Man i det Nittende Aarhundrede stedse bedre lære at betragte den store politiske Opgave, det er vor Tids Kald at løse, og paa hvis Løsning aabenbar Rigerne og Folkenes hele Fremtid beroer. ${ }^{5}$

Med Flid har jeg paa Titel-Bladet gjort Forskiel mellem "TroesBekiendelse" og "Tankegang" fordi vor Tids Forvirring for en stor Deel udspringer af, at man sammenblander alle sine Meninger, selv dem, Man kanske er ene om, med de faste Grund-Sætninger, som det er nødvendigt at enes om, og dette giver blandt Andet enhver bestaaende Forfatnings Angribere en stor Overlegenhed; thi de finde let dens svageste Side, og indbilde nu Forsvarerne sig at alt er lige rigtigt, spilde de ikke blot deres Kræfter, men kaste ved deres Nederlag Skygge paa Forfatningen i det Hele, hvis væsenlige Dele, rigtig forstaaede, dog tit vilde findes urokkelig. Paa en Tid, da hele StatsIndretningen allevegne trænger til en Grund-Forbedring, saa det giælder kun om, hvorfor den skal udgaae, af hvem den skal styres og hvortil den skal føre, maa en saadan Forvirring i Tankegangen især 
blive fordærvelig, og det er derfor den, jeg vil bekæmpe og stræbe om ikke at hæve, saa dog at formindske.

// (2r) Ved enhver Troes-Bekiendelse, maa dens Arlighed altid forudsættes, naar den skal have mindste Værd; og burde derfor allevegne indledes med en Forsagelse, som her maa lyde saaledes: jeg forsager Falskheden og alle dens Gierninger og alt dens Veesen, hvortil ogsaa høre de mange Alt og Intet sigende Ord, Partierne nu om Stunder sædvanlig giøre deels til deres eget Løsen ${ }^{6}$ og deels til Modstandernes Kiendemærke. Herved er man sig vist nok tit ei mindste Falskhed bevidst, men en saadan svævende og tvetydig Talebrug hører derfor ligevist til dens Væsen og giør usigelig megen Skade ${ }^{7}$. Saadanne Tvetulle-Ord, som Constitution og Forfatning, Reform, Liberalitet, Servilitet, Absolutisme ${ }^{8}$ hvis Herkomst oven i Købet er de Fleste ubekiendt, maae ærlige Folk derfor aldrig bruge i deres politiske Troes-Bekiendelse eller giøre til deres Løsen, da de derved, selv uden at ville det, skuffe baade sig selv og andre, som om Striden og Uenigheden gjaldt noget ganske Andet end hvad der virkelig er det store Tvistens Æble, den Magt og Myndighed nemlig, der, hvor man vil have et borgerligt Selskab, umuelig kan fordeles paa Alle, men maa hvile etsteds, enten det saa er hos Én eller Flere, hos hvad der kaldes Øvrighed eller hos dem, der kaldes Undersaatter. ${ }^{9}$

Derfor er min første Troes-Artikel at $^{10} \mathrm{i}$ et velindrettet borgerlig Selskab maae Een have Ret til at byde og alle Undersaatterne være pligtige til at lyde.

Min anden Troes-Artikel er derimod den, at ligesaavel som Øvrigheden har fri Haand, maa Undersaatterne have fri Mund, have deres Frisprog.

Min tredje Troes-Artikel er den, at Mennesket er ikke til for Statens eller det borgerlige Selskabs Skyld, men Staten med alle sine Indretninger er til for Menneskets Skyld, saa ${ }^{11}$ virkelige MenneskeRettigheder maa ingen Øvrighed krænke, skal alle Undersaatter nyde.

Dette skulde derfor efter min Overbeviisning være den korte men fyndige og uforanderlige Grundlov i alle Stater, thi hverken kan den nogensinde trænge til Forandring, eller, efter Historiens Vidnesbyrd, uden Skade taale Nogen, da Bestemtheden i Udtrykkene er parret med en Almindelighed, der lader Rum for Læmpningen efter alle forekommende Omstændigheder. 
Fasc. 189.II Udkast til et politisk Skrift (ca 1840 ved kongeskiftet?)

\section{( Læg 1) (1r)}

Der er for ethvert Folk to store politiske Spørgsmaal, hvoraf man i vore Dage desværre altid vil have det bestemt først, som, hvor det trænger til Bestemmelse, skulde bie til Sidst, og Følgen $\mathrm{er}^{12}$ at det vigtigste Spørgsmaal besvares enten slet ikke, eller dog yderlig slet. Hvem skal regiere og hvordan skal der regieres? Det er Spørgsmaalene, hvoraf det første overalt hvor der er en Regiering, besvarer sig selv, og skulde, hvor der ingen er, altid besvares sidst, da det aabenbar maa være alle ${ }^{13}$ fribaarne Sjæle langt vigtigere hvordan de regieres, end hvad Navn Regieringen fører, saa først naar det er fastsat hvordan, bliver Spørgsmaalet: af hvem man tør haabe at blive saaledes regieret? Uagtet der nu imidlertid i hele vor Christenhed baade er en Regiering og Foranstaltning til at den kan vedblive at ligne sig selv, saa bliver man dog, hvor man tør, bestandig ved at trættes om enten den Regiering skal blive ved, eller man skal have en anden, istedenfor at udvikle hvordan der skal regieres, hvem der saa end staaer for Styret, og da prøve hvorvidt man kan formaae den nærværende Regiering til at følge de Regler. Hvad der endnu mere indvikler Sagen og giør den hele Forhandling til uendeligt Vrævl, er at de fleste paastaaer, det er ikke Regieringen, men Undersaatterne, der skal regiere, thi // (2v) en saadan Selvmodsigelse hævner sig naturligviis frygtelig paa den Mand, der forfægter den.

Anvende vi nu dette paa Danmark da finde vi, at ingensteds er Spørgsmaalet om hvem der skal regiere, klarere bestemt, thi det skal aabenbar efter Folke-Stemmens ${ }^{14}$ fri Yttring Frederik den tredjes Afkom paa Mands og Kvinde-Side, saalænge den findes, og den skal regiere uindskrænket, altsaa ikke lade sig regiere af Nogen. Spørgsmaalet, hvordan her skal regieres er derimod langtfra at være saa klart bestemt, saa her var en nærmere Bestemmelse saa ønskelig, at FolkeStemmen af al Magt burde drive derpaa. Vist nok følger det af sig selv, at naar et Folk frit overdrager den forhen deelte Regiering til en Enkeltmand, da er det ei for at regieres slettere men bedre end før, saa han skal naturligviis altid see paa "fcelles Bedste", men da Enkeltmanden paa Thronen, der maa see det Meste med Andres Øine, let kan see feil, og Egenkiærligheden let forlede ham til at glemme Andre over sig selv, saa bør det baade være udtalt saa klart som mueligt hvad der er fælles Bedste og der maa være aabnet Folket Leilighed til i hvert enkelt Tilfælde at lade sin Stemme høre om, hvorvidt fælles Bedste rammes eller forfeiles af Regieringen. ${ }^{15}$ Ingen // (2r) af Delene er skedt i "Kongeloven," der vel lover Folket en 
"faderlig" og "christelig" Regiering til Giengæld for dets grændseløse Tillid, men taber sig i en aldeles ensidig Udvikling af Enevoldsmagtens Begreb og Arvefølgens Enkeltheder, saa Alt skal beroe paa hvad hver enkelt Arve og Enevolds-Konge vil behage at kalde "faderligt og christeligt" og hvorvidt det kan træffe sig, at han bliver oplyst om hvad der er Folkets Ønske og Rigets Tarv. ${ }^{16}$ Om nu ogsaa vore Fædre havde erklæret sig fornøiede med en saadan Grundlov, da havde det aabenbar kun været en Feiltagelse af Mangel paa Oplysning, som vi saameget mere maatte forlange rettet, som Tiden klarlig har viist, at fælles Bedste derved ingenlunde var betrygget men udsat for den største Fare; thi efter Christian den Femtes Lov, ${ }^{17}$ og medfølgende Censur, var alle offenlige Veie til Oplysning om Landets sande Tarv lukkede og al Klage over Regieringen stemplet til Majestætsforbrydelse. Kongeloven har imidlertid blandt alle sine Lyder som Grundlov, den Grundfeil aldrig at have været Folket forelagt til Betænkning og ei at være udgivet af Frederik den tredje, der, hvis Nogen havde Fuldmagt til eensidig at give Danmark en Grundlov, aabenbar var den Eneste, som havde den.

Ligesaa eensidig er den saakaldte Grundlov // (3r) om Indfødsretten givet og ligesaa den om Folkeraadet ${ }^{18}$, hvori mange har villet finde en Strid med Kongeloven, saa hvis der skal blive nogen Orden i Danmarks Grundforfatning og nogen Betryggelse for Folke-Stemmen, da maa enten Kongen forelægge Raadet, eller Raadet foreslaae Kongen en ny Grundlov, hvorved, Enevoldsmagten ubeskaaret, Folkets Rettigheder og Folkestemmens Rettigheder udtrykkelig erkiendes og alle følgende Enevoldskonger forpligtes, thi baade bør det være klart at Kongen i Danmark vel har Magt men ingenlunde Ret til at giøre Uret, og at den fri Folke-Stemme ligesaavel som den fri Kongemagt hører til vor Forfatnings urokkelige Grundvold. ${ }^{19}$

Disse Folke-Rettigheder ${ }^{20}$ er nu aabenbar saamegen Sikkerhed paa Person og Eiendom, og saamegen Frihed i alle Maader, som Enevoldsmagten kan skaffe og fælles Bedste tillade, og da fremfor Alt Sikkerhed paa, at ved Alt hvad disse Ting angaaer, følgelig om Krig og Fred, Skatter og Paalæg o.s.v. skal Folke-Stemmen have Lov og Leilighed til at yttre sig frit.

\section{Noter}

1 Grundtvig citerer Prædikerens bog 3,7 i Det Gamle Testamente, ifølge traditionen forfattet af den vise kong Salomon.

2 Grundtvig benytter i overensstemmelse med datidig sprogbrug ordet "Selskab" $\mathrm{i}$ betydningen samfund. 
Grundtvig overstreger her "af Thronen og Enevoldsmagten tale langt friere end under den gamle Landsfader" og gør dermed tekstens forsvar for den - ganske vist opinionsstyrede - enevælde mindre eksplicit.

Baggrunden er her som nævnt $\mathrm{i}$ indledningen Christian VIII's magtovertagelse i 1839. I Danmark ventedes det, at han, der i Norge havde givet den frie Eidsvollforfatning, også ville give Danmark folkestyre.

Grundtvigs epokebevidsthed er her lige så stærk som i eksempelvis Nordens Mythologi, US V, 411.

6 "Løsen" egentlig feltråb eller parole.

7 Grundtvigs parallelisering mellem det borgerlige og det kirkelige samfunds "Grundlov" kommer i teksten klart til udtryk gennem opbygningen af den politiske trosbekendelse som et sidestykke til den apostoliske trosbekendelse.

8 "Tvetulle" betyder hermafrodit, "Constitution" betyder statsforfatning, "Reform" fornyelse, "Liberalitet" frisind, "Servilitet" underdanighed og "Absolutisme" enevælde.

9 Med formuleringen markerer Grundtvig sin tilslutning til den opinionsstyrede enevældes placering af magten hos kongen.

10 Grundtvig streger "hvor Undersaatterne skal byde, og Øvrigheden skal lyde, der skyder det borgerlige Selskab Hovedløg og kommer bittert til at undgiælde sin Selvmodsigelse" og svækker derved sin kritik af enevældens afskaffelse en smule.

11 Grundtvig streger her "alle" og skærper derved tekstens implicitte modstilling af sande og falske menneskerettigheder.

12 Grundtvig sletter "blandt andet".

13 Grundtvig streger "tænkende Mennesker" og forskyder dermed betydningen fra intellektuelle til mennesker med forståelse for og ønske om frihed.

14 Grundtvig streger "første Ord" til fordel for "fri Yttring".

15 Grundtvig knytter med vendingen "fælles Bedste" til ved de overvejelser, der i kombination med tanken om almenviljen fra det 18 . århundredes midte og frem bestemmer den kontinentale forfatningsdiskussion, se J. Leisner 1972, 208-213. Udtrykket er Grundtvigs almindelige formel for, hvad der bør udgøre samfundets målsætning, se eksempelvis HGS II, 190.

16 Kongeloven er udarbejdet af Peder Schumacher Griffenfeld i 1665, se oplysningerne $\mathrm{i}$ indledningen til teksten.

17 Danske Lov, den af Christian V udstedte almindelige lovbog for Danmark fra 1683.

18 Loven om indfødsretten udformedes af Ove Høegh Guldberg $1776 \mathrm{og}$ loven om de rådgivende stænderforsamlinger gav Frederik VI 1834.

19 Gensidighedsaspektet i forholdet mellem konge og folk - at begge har rettigheder og pligter - kommer her tydeligt til udtryk.

20 Begrebet folkerettighed må her forstås som de rettigheder, folket $\mathrm{i}$ betydningen summen af borgere besidder. Samtidig synes udtrykket at alludere til begrebet folkeret. 